\title{
作業環境測定基準に基づく吸入性粉じんと ロウボリウムサンプラ用多段分粒装置の性能評価
}

明星敏彦

独立行政法人産業医学総合研究所作業環境計測研究部

抄録：作業環境測定基準に基づく吸入性粉じんとロウボ リウムサンプラ用多段分粒装置の性能評価 : 明星敏彦. 独立行政法人産業医学総合研究所作業環境計測研究部— 粉じん捕集用に広く用いられているロウボリウムサンプ ラの粉じん分級装置である水平重力分級装置である多段 分粒装置（柴田科学 C-30 型）の静止空間からの粒子の 粒径別の分級特性を計測した。この測定結果と装置の理 論的な分級特性および作業環境における吸入性粉じんの 関係を比較検討した。吸入性粉じんはISO 7708 を基礎 にした特性が新たに作業環境測定基準に導入された。吸 入性粉じんとサンプラの特性との偏りを計算した。結果 は多段分粒装置を $5 \mu \mathrm{m} 50 \%$ カットの条件で用いた場合 は過大評価し， $4 \mu \mathrm{m} 50 \%$ 50 カの条件で用いた場合は 過小評価した。

(産衛誌 2005; 47: 239-245)

キーワード : Respirable dust, Low-volume air sampler, Sampling convention, Aerosol

\section{I .はじめに}

作業環境測定基準 (厚生労働省告示) ${ }^{1)}$ において鉱物 性粉じんの測定などに関係する吸入性粉じんの定義が改 正された。呼吸で吸い达まれた空気は鼻, 口から咽喉部, 気管，気管支部を通り，肺胞部に至る。この空気ととも に吸引された粉じん粒子はその粒径により異なる部位に 沈着する. 改正された吸入性粉じんの定義は ISO 7708 (Air quality-Particle size fraction definitions for healthrelated sampling) ${ }^{2)}$ と同一である. ISO 7708 は気中か ら鼻孔または口を通って吸入される粒子 (吸引性粉じん, Inhalable convention), さらに咽頭を越えて肺に向かう

2005 年 3 月 26 日受付； 2005 年 8 月 8 日受理

連絡先：明星敏彦 † 214-8585 川崎市多摩区長尾 6-21-1 独立行政法人産業医学総合研究所作業環境計測研究部 (e-mail : myojo@niih.go.jp)
粒子 (咽頭通過性粉じん, Thoracic convention), 肺胞 まで届く粒子（吸入性粉じん, Respirable convention) について通過率を示している. 通過率の值は年齢, 体格, 呼吸器の疾患の有無により異なるが, ISO 7708 では健 康な成人とハイリスクグループについて定義されてい る.

浮遊するすべての粒子の量である総粉じん量に比べ て，頭部を粒径別の分級特性を持つ粉じんサンプラと考 え，大きな粒子は吸引されないと考えるようになった。 どのような粒径の粒子まで吸引されるかを模擬人頭のサ ンプラ，風洞， $100 \mu \mathrm{m}$ までの試験粉じんを使用して計 測した ${ }^{3-6)}$ 。これらの結果を基にISO 7708 では粒径 $\mathrm{d}_{\mathrm{p}}$ の吸引性粉じんは $4 \mathrm{~m} / \mathrm{s}$ 以下の風速では 1) 式で示され る通過率 $\mathrm{E}_{\mathrm{I}}$ をもつと規定されている.

$$
\mathrm{E}_{\mathrm{I}}=0.5\left(1+\mathrm{e}^{-0.06 \mathrm{dp}}\right)
$$

この吸引性粉じんサンプラとして，十分な粒子の取り 込み速度を得るため取り込み口をオープンフェイスより 絞った形状のサンプラヘッドが市販されている ${ }^{7)}$. 吸引 性粉じんの内, この吸入性粉じんの通過率 $\mathrm{E}_{\mathrm{R}}$ は次式で 表される11)

$\mathrm{E}_{\mathrm{R}}=1-\mathrm{F}(\mathrm{x})$

2）式には以下を代入する。

$$
\begin{aligned}
& \mathrm{F}(\mathrm{x})=\frac{1}{\sqrt{2 \pi}} \int_{-\infty}^{\mathrm{x}} \mathrm{e}^{-\frac{\mathrm{x}^{2}}{2}} \mathrm{dx} \\
& \mathrm{x}=\ln \left(\mathrm{d}_{\mathrm{p}} / \Gamma\right) / \ln (\Sigma) \\
& \Gamma=4.25 \mu \mathrm{m}, \quad \Sigma=1.5
\end{aligned}
$$

吸引された全粒子の内，肺胞まで到達する吸入性粉じ んは1）式と 2）式の積で表される.

$$
\mathrm{P}\left(\mathrm{d}_{\mathrm{p}}\right)=\mathrm{E}_{\mathrm{I}} \cdot \mathrm{E}_{\mathrm{R}}
$$

これらの式は新しい作業環境测定基準 ${ }^{1)}$ でも示され ている. 本文では以下これをISO吸入性粉じん曲線と 呼ぶ. 従来, 規定されていた吸入性粉じんは, BMRC 


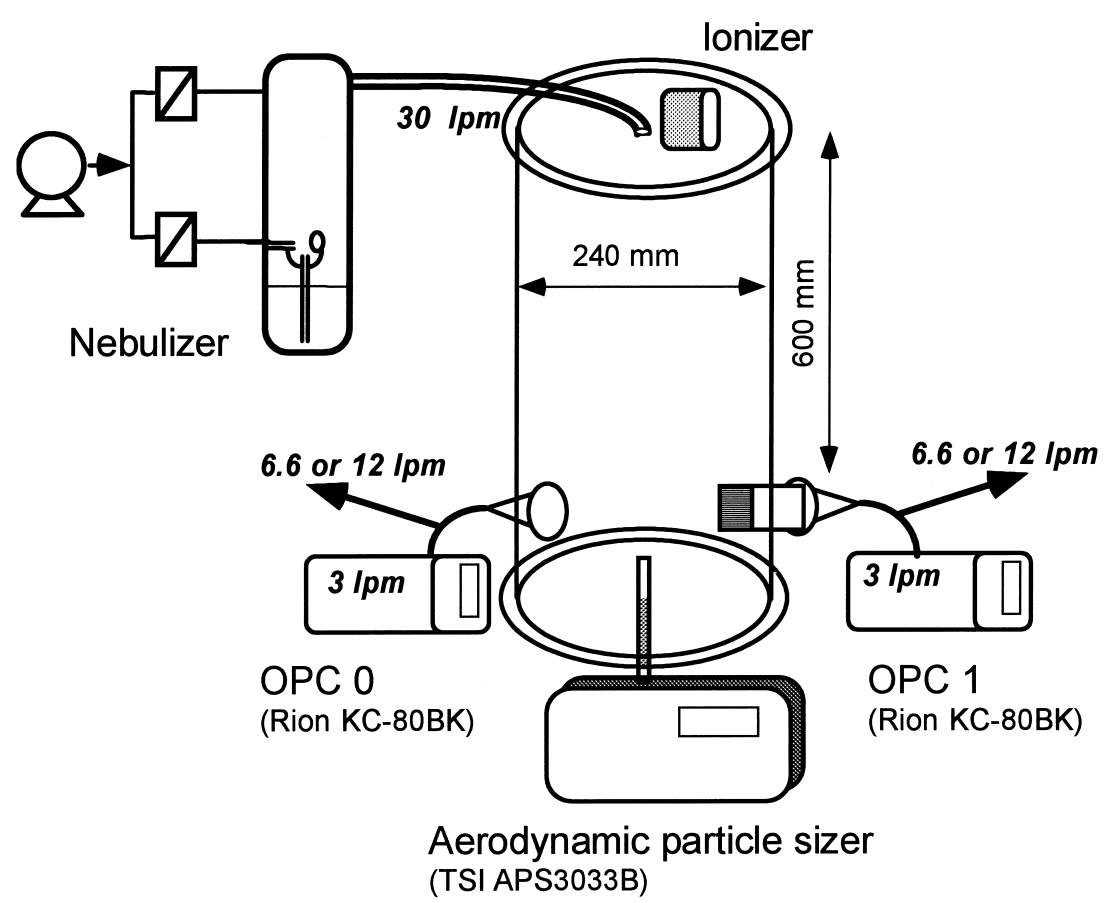

Fig. 1. Experimental apparatus.

の通過率 ${ }^{8)}$ と同一で $50 \%$ カット径は $5 \mu \mathrm{m}$ であった ${ }^{9)}$. 一方，米国の旧 $\mathrm{ACGIH}^{10)}$ の通過率では $50 \%$ カット径 は3.5 $\mu \mathrm{m}$ であった. 3）式で規定されるISOの吸入性粉 じんの分級特性は両者の中間で $50 \%$ カ となっている.

以上の通過率は呼吸器内での粒子の沈着現象から得ら れたもので，特定の分粒装置を意味していない. そのた め粉じん計測のためのサンプラの ISO 吸入性粉じん曲 線への適合性について，これまで多くの研究 ${ }^{12-19)}$ がな されている. しかしながら, 諸外国では個人サンプリン グの手法が主に使用され，これらのサンプラはほとんど が吸引流量 $3 \mathrm{l} / \mathrm{min}$ 以下であるのに対し，わが国では定 置型のロウボリウムサンプラを用いて吸引流量 $10 \mathrm{l} / \mathrm{min}$ 以上で粉じん濃度を測定することが多い20)。さらに粉 じん測定の目的は多くの場合, 粉じん相対濃度計の質量 濃度換算係数（K值）の決定である. 国内では環境中の 粉じん計測のためのロウボリウムサンプラの JIS Z8814 ${ }^{21)}$ に粒径別捕集効率の求め方が規定されている. 本研究では作業環境測定で広く使用されている水平重力 分級の原理を用いる多段型分粒装置についてその通過率 を粒径別に計測し，この通過率を基に対数正規分布を仮 定した粉じんの通過率を計算し, ISO 7708 吸入性粉じ んの通過率と比較検討した。

\section{II．実験装置と方法}

数 $\mu \mathrm{m}$ の単分散粒子を発生してエアロゾル化する場 合, 振動オリフィスエアロゾル発生器がしばしば用いら
れる ${ }^{22)}$.これは染料を含む水溶液を振動オリフィスで 一定の大きさのミストとし，これを乾燥して染料粒子を 得るものである，本装置の粒子発生量は少ないので，染 料粒子を捕集後, 溶出させ濃度を測定することにより, 粒径別通過率を求める。他に粒度を調整した粉体を分散 することで，高濃度のミクロン粒子エアロゾルを得る場 合もある ${ }^{7)}$ 。一方，多分散粒子をエアロゾル化し，これ を粒径別に計測することで, 粒径別の通過率を求めるこ とが可能である ${ }^{23-25)}$. わが国ではJIS Z8814に単分散 ポリスチレンラテックス粒子（JIS Z890126）に示され ている。以下 PSL粒子) 抢よび光散乱粒子計測装置 （以下 OPC）を用いて粒径別の分粒特性を測定する方法 が示されている。

Figure 1 にJIS Z8814に準じて, 本研究で用いた実験 装置の全体図を示す。これを用いて, 旧測定基準 2 条 2 にある粒径別の粉じん透過率を実現する装置として広く 使用されていた多段型分粒装置（柴田科学 C-30型）の 粒径別の通過率を計測した。単分散のPSL粒子を 2 回 蒸留水に分散し，ネブライザーで噴霧・乾燥して試験粒 子エアロゾルとし, 乾燥空気を加えて, 円筒容器上方か ら供給した。筒容器は直径 $24 \mathrm{~cm}$ で長さ $100 \mathrm{~cm}$ であ り，上から $60 \mathrm{~cm}$ に試験すべき多段分粒装置と対照とな る多段分粒部を取り外したベルマウス型の受け用部品 （フィルタホルダに相当するが，フィルタは挿入してい ない）を設置した。これらの装置下流に OPC（リオン KC-80BK）を2台設置して, PSL粒子の濃度を並行し て計測した．2台の OPCの機差は別途並行測定で確認 
した。 OPC は吸引流量が $3 \mathrm{l} / \mathrm{min}$ であり，必要な流量は 追加の真空ポンプで吸引し, 全流量は流量校正装置 (SKC DryCal) で確認した。底部の空気力学径測定装 置（エアロダイナミックサイザーTSI APS33，以下 APS）は供給されたPSL粒子が複数粒子で凝集してい ないことを確認するために使用した．装置はクリーンル 一ム内に設置し, 円筒容器上部, 多段分級装置周辺, 下 部に隙間を設け，全体として少し負圧で周囲から清浄空 気が漏れ达む状態で運転した。

多段分粒装置による測定は，流量を規定の $15 \mathrm{l} / \mathrm{min}$ の他に, $50 \%$ カット径が $4 \mu \mathrm{m}$ となる $9.6 \mathrm{I} / \mathrm{min}$ でも並行 測定を行った．多段分粒装置の詳細は既に示されている が ${ }^{20)}$, 以下の式は, 粒子の水平重力沈降分級の理論通 過率から導出されたものである.

$$
\begin{array}{ll}
\mathrm{P}\left(\mathrm{d}_{\mathrm{p}}\right)=1-\frac{\mathrm{d}_{\mathrm{p}}^{2}}{\mathrm{~d}_{\mathrm{p} 0}^{2}} & \left(\mathrm{~d}_{\mathrm{p}} \leq \mathrm{d}_{\mathrm{p} 0}\right) \\
\mathrm{p}\left(\mathrm{d}_{\mathrm{p}}\right)=0 & \left(\mathrm{~d}_{\mathrm{p}} \geq \mathrm{d}_{\mathrm{p} 0}\right) \\
\mathrm{d}_{\mathrm{p} 0}=\left(\frac{18 \eta \mathrm{F}}{\rho \mathrm{gLWN}}\right)^{0.5} &
\end{array}
$$

ここで F は流量， $\eta$ は空気の粘度， $\mathrm{L}, \mathrm{W}, \mathrm{N}$ は多段分 粒装置の長さ, 幅, 段数を示す. $\mathrm{d}_{\mathrm{p} 0}$ は $100 \%$ 捕集され る粒径で, 計算上 $7.07 \mu \mathrm{m}$ となるように上式を用いてそ の大きさと流量が決定されている．本文では以下これを $\mathrm{BMRC}$ 曲線と呼ぶ。また $50 \%$ カット径が $4 \mu \mathrm{m}$ となる 場合には $\mathrm{dp} 0$ は $5.66 \mu \mathrm{m}$ となる. 本文では以下これを $4 \mu \mathrm{m} \mathrm{BMRC}$ 曲線と呼ぶ.

試験用エアロゾルは単分散の PSL粒子を 2 回蒸留水 に分散，これをガラス製ネブライザーで噴霧乾燥してエ アロゾルを得た。ここではネブライザーの噴霧流量を $15 \mathrm{l} / \mathrm{min}$ た希釈流量を $15 \mathrm{l} / \mathrm{min}$ ，噴霧圧力を $0.045 \mathrm{MPa}$ として運転した。試験粒子は容器の上から下 へ平均流速 $1 \mathrm{~cm} / \mathrm{min}$ で流れる. 直流式除電器 (KD-110, 春日電気）により両極イオン雾囲気中にエアロゾル粒子 を通過させることで粒子の除電を試みた。粒径 1 〜 $7 \mu \mathrm{m}$ の 7 種類の PSL 粒子を使用して, それぞれの粒径 ごとに別個に上記の方法でエアロゾル発生させた．本研 究で使用したPSL 粒子の粒径を Table 1 に示した. 表は 各PSL 粒子の公称粒径と測定の不確実性からくる公称 值の範囲（Uncertainty）を示している。過去にはPSL 粒子の公称值と実測值にかなりの相違があることが指摘 されていたが，現在は標準粒子の粒径に関する品質管理 のシステム（PSL粒子のメーカーと産業技術総合研究 所計測標準研究部門や米国国立標準技術研究所の間で標 準粒子の粒径のトレーサビリティを保証するシステム) が整備されている.

OPC はエアロゾルをノズルから細く測定部に導入し，
Table 1. PSL particles used in this study

\begin{tabular}{lllrc}
\hline No. & Manufacturer & Name & \multicolumn{2}{c}{ Nominal value } \\
& & & $\mathrm{d}_{\mathrm{p}}(\mu \mathrm{m})$ & $\mathrm{U}^{*}(\mu \mathrm{m})$ \\
\hline A & JSR & SC-127-S & 1.274 & 0.029 \\
B & JSR & SS-022-P & 2.047 & 0.046 \\
C & JSR & SS-032-P & 3.210 & 0.072 \\
D & Duke & 4204A & 4.000 & 0.033 \\
E & JSR & SS-052-P & 5.125 & 0.115 \\
F & Duke & 4206A & 5.990 & 0.045 \\
G & JSR & SS-072-P & 7.123 & 0.160 \\
\hline
\end{tabular}

*: Uncertainty of nominal diameter.

これに光を照射して粒子からの散乱光を検出器で受光 し,この検出器の信号を電気信号に変換することにより， 粒子数と粒径を得る装置である。散乱光はパルス状で, その強度は粒子の大きさに対応し，その数は粒子の数に 対応する。使用した OPC は粒径別に 5 チャンネルに, それぞれ $0.3 ， 0.5 ， 1.0,2.0 ， 5.0 \mu \mathrm{m}$ 以上の粒子数を積算 する機能を持つ半導体レーザー型 OPCである．測定し た粒子の大きさを判別するための電気信号の閾值(電圧) はメーカーによって校正・設定されている．粒径分別機 能の校正には本研究で用いたような単分散 PSL粒子を 用いて校正し ${ }^{27)}$ ，トレーサビリテイ証明書が付属して いる，校正粒子と同じ PSL粒子を使用すれば，表示さ れる粒径は同一である。ただし，2台の OPCを用いる 場合は装置間の若干の機差は存在し，5つの閾值毎に機 差を考慮する必要がある.

同じ終末沈降速度を持つ密度 $\rho_{\mathrm{p}}$ が $1 \mathrm{~g} / \mathrm{cm}^{3}$ の球形粒 子の粒径を,対象粒子の空気力学相当径と定義している. 空気力学相当径を計測する装置としてAPSを使用した. これはノズルを飛び出したエアロゾル粒子が 2 本のレー ザービームを通過した時に出す散乱光を受光器で 2 個の パルス信号に変換し，その飛行時間を計測することによ り粒子の質量を求める装置である ${ }^{28)}$. APS は粒径範囲 $0.5 \sim 25 \mu \mathrm{m}$ を 56 チャンネルに分割・測定し，ミクロン サイズの粒子計測に適している. APSは OPC 以上の性 能を持つが，国内で使用されることが少なく，規定もな いのでここでは補助的に使用した。

\section{III. 結果と考察}

\section{1. 標準粒子を用いた多段分粒装置の通過率測定結果}

Figure 2 にAPS による測定の 1 例を示す. 2 枚の図は, $7.123 \mu \mathrm{m}$ PSL 粒子の粉じんの同じ測定デー夕を個数基 準（A）と質量基準（B）で示したものである，質量基 準平均径は $7.7 \mu \mathrm{m}$ と PSL 粒子公称值より少し大きな值 を示していた，大量発生を目指すために，かなり高濃度 の PSL 粒子懸濁液を噴霧しているが，図からは複数の PSL 粒子からなる凝集体は観察されず，ほとんどが単 

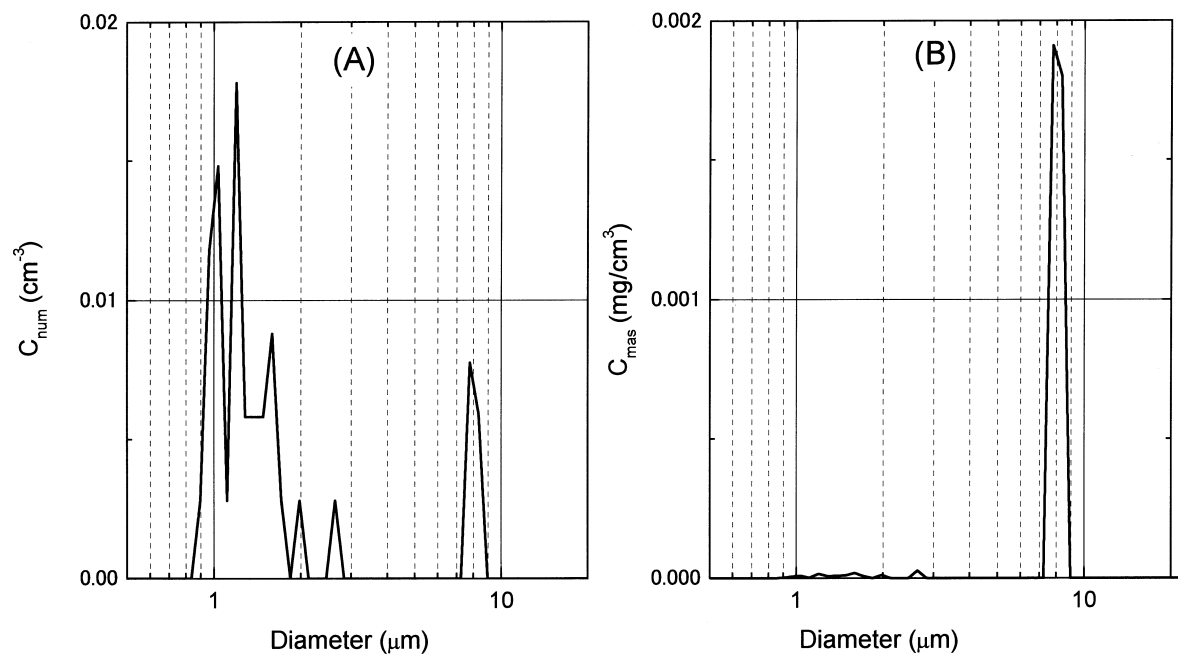

Fig. 2. Size distribution of PSL particles (nominal diameter: $7.123 \mu \mathrm{m}$ ) by Aerodynamic Particle Sizer (APS33, TSI Inc.)

(A): number distribution, (B): mass distribution.

Table 2. Parallel test results of two OPCs used in this study

\begin{tabular}{|c|c|c|c|c|}
\hline \multirow[t]{2}{*}{ PSL particles } & \multicolumn{2}{|c|}{ Ratio $\left(\mathrm{P}_{0} / \mathrm{P}_{1}\right)$} & \multirow[t]{2}{*}{ Size range } & \multirow{2}{*}{$\begin{array}{c}\text { Average Conc. } \\
\text { (particles/3 I) }\end{array}$} \\
\hline & Average & STD & & \\
\hline $1.274 \mu \mathrm{m}$ & $106.4 \%$ & $0.9 \%$ & $>0.5 \mu \mathrm{m}$ & 64,817 \\
\hline $2.047 \mu \mathrm{m}$ & $102.2 \%$ & $2.3 \%$ & $>1 \mu \mathrm{m}$ & 3,499 \\
\hline $3.210 \mu \mathrm{m}$ & $99.9 \%$ & $4.8 \%$ & $>2 \mu \mathrm{m}$ & 702.9 \\
\hline $5.125 \mu \mathrm{m}$ & $108.3 \%$ & $13.1 \%$ & $>2 \mu \mathrm{m}$ & 217.7 \\
\hline
\end{tabular}

*: PSL particle concentration changed for each run.

粒子からなることがわかる. 図（A）では $1.0 \mu \mathrm{m}$ 程度 の粒子も存在していることがわかる。これは懸濁液中の 不純物が噴霧蒸発して生成するもので, PSL粒子では ない.これらの粒子は OPCの測定範囲を選択すること で排除することができる.

2 台の OPCの併行測定試験（機差試験）の結果を Table 2 に示す. OPC の計測は 1 分間計測， 30 秒間休み を10回くり返した．表は 2 台の濃度比の平均と標準偏 差抢よびそのときの粒子濃度を示す．結果として，入口 濃度を測定している装置の方が数\%高い濃度を示す場合 があった．前述のように信号の電気的な閾值がそれぞれ 設定されており，粒径によって機差が異なることが考え られる。これは通過率が高い場合（粒径の小さい場合） には相対的に影響を受ける。しかし，測定した $5 \mu \mathrm{m}$ 以 上の粒子では下流濃度が低いため影響は少ない。 $1.274 \mu \mathrm{mPSL}$ 粒子については $100 \%$ 通過を計算補正して 示した. Table 2 に示すように $3.210 \mu \mathrm{mPSL}$ 粒子以上で は, 平均の機差よりも標準偏差の方が大きく, 通過率に 与える影響も少ないので補正は加えていない。

Figure 3 にBMRC 曲線と $4 \mu \mathrm{m}$ BMRC曲線および 3 ) 式で表される ISO 吸入性粉じん曲線を示す．各点は，1

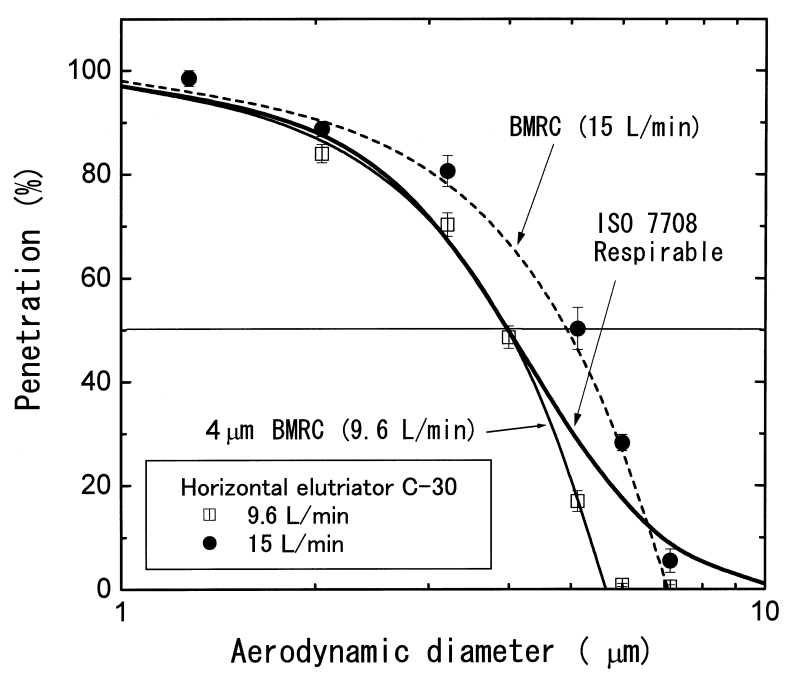

Fig. 3. Penetration of horizontal elutriator sampler. Theoretical curves and measured data.

分間測定を 10 回行って得た通過率の平均と分散を示し ている.2つの BMRC曲線は流量 $15 \mathrm{l} / \mathrm{min}$ と $9.6 \mathrm{l} / \mathrm{min}$ にそれぞれ対応するので，この流量について多段型分粒 装置を用い，PSL粒子の通過率を測定した結果も粒径 
毎に示した。実測結果は，それぞれの BMRC 曲線と非 常によい一致を示している. 図からこの多段型分粒装置 を $15 \mathrm{l} / \mathrm{min}$ で運転した場合, 改正前の作業環境測定基 準 ${ }^{1)}$ を満たしていることが確認された．静止空間から の粉じんサンプリングにおいて多段型分粒装置は BMRC 曲線とよい一致を示すことは英国の炭坑で用い られる同種のサンプリング装置（MRE113A）でも既に 示されている ${ }^{29)}$. しかし，この装置は吸引流量が $2.5 \mathrm{l} / \mathrm{min}$ と多くない。また装置に流入する粒子が速度 を持つ場合はより大きな粒子を取り込むことが指摘され ている. 粒子通過率からはイオナイザの効果は明確には 見えなかった。

\section{2. 粉じん粒度分布を仮定した捕集量の計算結果}

ISO 吸入性粉じんの通過率曲線は粒子の呼吸器内での 沈着を基準にしており，特定の分粒装置の特性を基にし ていない. Fig. 3 に示すように 2 つの BMRC 曲線は実験 的に確認され，多段型分粒装置を用い $9.6 \mathrm{I} / \mathrm{min}$ で捕集 すれば50\%カット径 $4 \mu \mathrm{m}$ を満たしていた。広い粒度分 布を持つ粉じんについて，これらの分級特性はどの程度 ISO 吸入性粉じん曲線と一致するかを予測した方法と結 果を以下に示す.

粉じんの粒度分布では対数正規分布を当てはめること が多い. 対数正規分布の密度関数 $\mathrm{f}(\mathrm{dp})$ は次の式で表 される。

$$
\mathrm{f}(\mathrm{x})=\frac{1}{\log \sigma \sqrt{2 \pi}} \mathrm{e}^{-\frac{\left(\log \mathrm{dp}-\log \mathrm{dp} 5_{0}\right)^{2}}{2 \log ^{2} \sigma}}
$$

この式を用いると正規分布と同様に質量基準幾何平均 径 $\mathrm{dp}_{50}$ と幾何標準偏差 $\sigma$ の 2 の值によって粒度分布

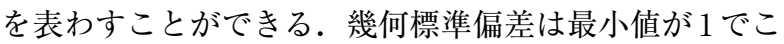
れは単分散であり，現実は 1.5 から 2.5 程度である。粒 子の通過率 $\mathrm{P}(\mathrm{dp})$ を上述の ISO の吸入性粒子と 2 つの $\mathrm{BMRC}$ 曲線と仮定し, $\mathrm{dp}_{50}$ と $\sigma$ の值を適宜代入すると, 分粒装置前の濃度を 1 とする装置後の濃度 $W$ を求める ことができる.

$$
W=\int_{0}^{\infty} P\left(d_{p}\right) f\left(d_{p}\right) d\left(\log d_{p}\right)
$$

実験的に多分散粒子での濃度測定をする代わりに，計 算機を用いて濃度の推定を行った。適当な粒度分布を持 つ粉じんがこれらの分粒装置を通過した場合の粉じんの 重量比を6）式を用いて計算した。計算には粉じん粒度 分布として 5）式を仮定し， $\mathrm{dp}_{50}$ で 0.5，1，3，5，8， $10,12 \mu \mathrm{m}$ ，幾何標準偏差 $\sigma$ で 1.0，1.3，1.7，2.0，2.5, 3.0 で行った. 6) 式の通過率 $\mathrm{P}\left(\mathrm{d}_{\mathrm{p}}\right)$ は Fig. 3 に示した 3 種類について，3次スプライン補間法を用いて任意の粒 径での值を代入し, 数值積分を行った ${ }^{30)}$ 。ここで使用
した通過率はスプライン補間法を用いなくても計算可能 であるが，実測などで粒径別の通過率が得られる場合に も本方法は応用可能である。

Figure 4は計算方法を示したもので，例として $\mathrm{dp}_{50}=5 \mu \mathrm{m}, \sigma=2.0$ の粒度分布の粉じん（図中の実線 で面積は 1）がISO 吸入性粉じんの通過率（図中の点線） をもつ分粒装置を通過した後の粒子の量を6）式から数 值積分で計算した。この值をそれぞれの分粒装置につい て計算し，ISO の吸入性粉じんを仮定した場合の粉じん 量を基準に比率を求めた. 例の粒度分布の場合, 計算上, ISO 吸入性粉じんで 0.38 (図中の斜線の面積), BMRC で 0.45 であり，両者の比は 1.16 であった.

Figure 5 は $15 \mathrm{l} / \mathrm{min} て ゙$ 多段分粒装置を運転した場合 と，ISO の吸入性粉じん量の比（ISO 基準）を等高線と して示したもので，バイアスマップと呼ばれている ${ }^{31)}$. 図中の $\mathrm{x}$ は先に計算した $\mathrm{dp}_{50}$ と $\sigma$ の組み合わせを示し

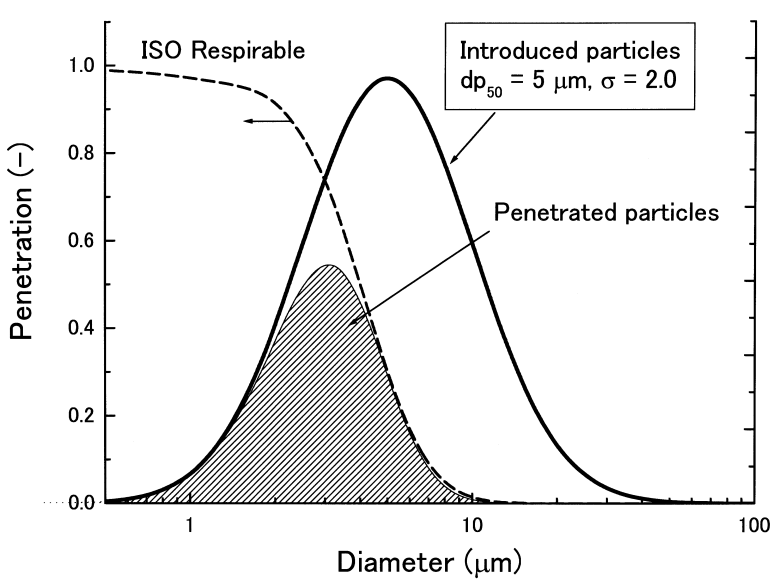

Fig. 4. Penetration and ratio of inlet particles and outlet particles through the sampler.

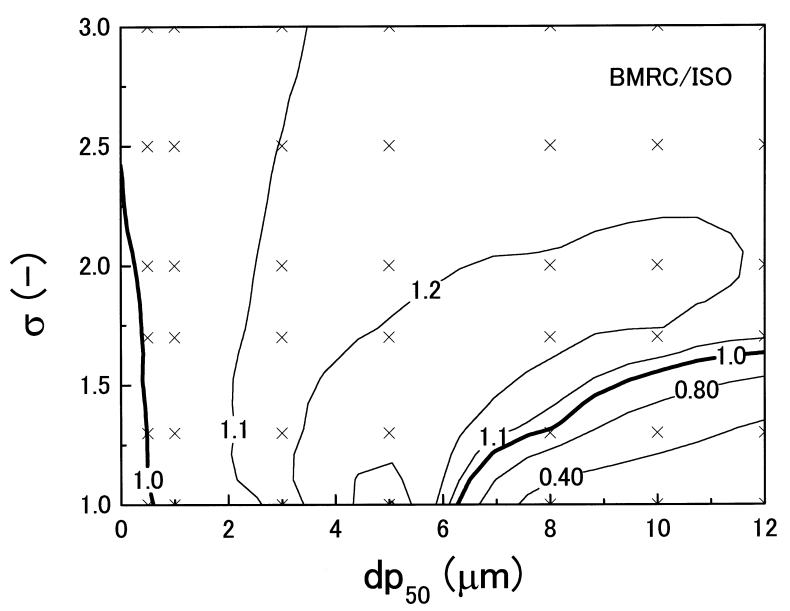

Fig. 5. Calculated bias map of BMRC/ISO

Symbols " $\mathrm{x}$ " in the figure show the conditions for bias calculation and the contour was drawn by Microcal Origin ver.6.1. 


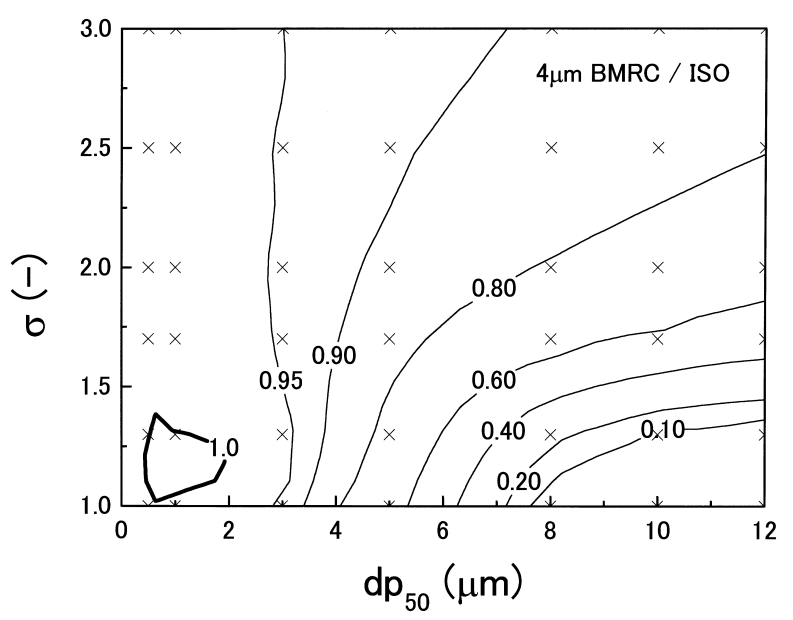

Fig. 6. Calculated bias map of $4 \mu \mathrm{mBMRC} / \mathrm{ISO}$. Symbols " $x$ " in the figure show the conditions for bias calculation and the contour was drawn by Microcal Origin ver.6.1.

ている．等高線図は Origin Ver. 6.1 (Microcal Software Inc., MA，USA）で計算・作図した。図で 1.0 の線は両 者の示す濃度が同じことを意味し，ほとんどの粒度分布 で，15l/minで多段分粒装置を運転した場合の方が $10 \%$ 程度濃度を高く見積もる。この結果はSoderholm ${ }^{32)}$ の計算結果ともほぼ一致している.

これに対して Fig. 6 は $9.6 \mathrm{I} / \mathrm{min} て ゙$ 多段分粒装置を運転 した場合と ISO 吸入性粉じん量の比（ISO 基準）のバイ アスマップである。結果は粒度分布によって異なり $90 \%$ から $10 \%$ まで減少し, 幾何平均径が大きい粉じん についてその濃度を過小評価する. 幾何標準偏差が大き い粉じんについてはその傾向は緩和される．この原因は Fig. 3 でわかるように，9.6 I/ $\mathrm{min}$ で多段分粒装置を運転 した場合はISO吸入性粉じんと仮定した場合に対して $4 \mu \mathrm{m}$ よりさい粒子ではほぼ同じ通過率を示すのに対 して，4 $\mu \mathrm{m}$ より大きな粒子では ISO 吸入性粉じんの方 が大きな粒子を取り込む割合が高いためである.

わが国におけるロウボリウムエアサンプラの使用目的 のほとんどが粉じん相対濃度計の質量濃度換算係数（K 值）の決定である. 光散乱方式の粉じん計では $1 \mu \mathrm{m}$ 以 下の粒子の質量基準の感度は $1 \mu \mathrm{m}$ 以上の粒子よりかな り高い. したがって，多くの場合には新しい吸入性粉じ ん分粒装置でサンプリングすると粉じん計の指示值は以 前と同じでも得られる質量濃度は旧型の分粒装置に比べ 低くなると予測される.

一方, 広く認められている $1 \mu \mathrm{m}$ 以下の粒子の肺胞部 での沈着率は実際には $40 \%$ 以下であり ${ }^{33)}, 1 \mu \mathrm{m}$ 以上の 粒子と重みが異なることになる．粉じん測定の目的が疫 学調査の場合, ISO 吸入性粉じんのように $1 \mu \mathrm{m}$ 以下の 粒子の通過率を $100 \%$ 近くに設定していることは望まし くないことが指摘されている ${ }^{34)}$.
本研究で示したように吸入性粉じんの分級特性を $\mathrm{BMRC}$ 曲線のままで曝露評価を行うことは見かけ上安 全側であるが，欧米諸国において ISO吸入性粉じんを 採用しており，健康影響のデー夕互換性の面からは ISO 吸入性粉じんに変更することは妥当と考える. そのため にはサンプリングに用いられる装置の分粒特性と，その バイアスマップを検討しなければならない. ISO吸入性 粉じん曲線との一致の程度についても今後検討されなけ ればならない。

\section{N. まとめ}

1）ロウボリウムエアサンプラで広く用いられている 多段分粒装置は重力沈降の理論通過率に従う分粒 特性を示すことを確認した。

2）多段分粒装置を $50 \%$ カット径 $4 \mu \mathrm{m}$ で運転すると ISO 吸入性粉じんに比べ, 粉じん濃度を過小評価 することがわかった。

3）多段分粒装置のみならず一般にサイクロンやイン パクタの原理を用いる分粒装置ではISO 吸入性粉 じんよりも急峻な分級特性を示すので，分粒特性 をどの程度合わせるかという基準策定が必要であ る.

4）通過率曲線の異なる分粒装置は粉じんの平均径と 偏差によって異なる濃度を与えるので, これを評 価するバイアスマップが各装置について必要であ る.

\section{文献}

1）厚生労働省告示第 368 号 平成 16 年 10 月 1 日. 2004.

2) ISO 7708 Air quality - Particle size fraction definitions for health-related sampling, 1995.

3) Ogden TL, Birkett JL. The human head as a dust sampler. In: Walton WH, eds. Inhaled Particles IV. Oxford: Pergamon Press, 1977: 93-105.

4) Ogden TL, Birkett JL. An inhalable-dust sampler for measuring the hazard from total airborne particulate. Ann Occup Hyg 1978; 21: 41-50.

5) Vincent JH, Mark D. Application of blunt sampler theory to the definition and measurement of inhalable dust. In: Walton WH, eds. Inhaled Particles V. Oxford: Pergamon Press, 1982: 3-19.

6) Armbruster $\mathrm{L}$, Breuer $\mathrm{H}$. Investigations into defining inhalable dust. In: Walton WH, eds. Inhaled Particles V. Oxford: Pergamon Press, 1982: 21-32.

7) Vincent JH, Mark D. Entry characteristics of practical workplace aerosol samplers in relation to the ISO recommendations. Ann Occup Hyg 1990; 34: 249-262.

8) Orenstein, AJ. Recommendations adopted by the Pneumoconiosis conference. In: Proc Pneumoconiosis conference, Johannesburg. London: J and A Churchill Ltd, 1960: 610-621. 
9）日本産業衛生学会許容濃度委員会. 許容濃度等の锥告 (2004 年度)。産衛誌 2004; 46: 130.

10) 2002 TLVs and BEIs, ACGIH 2002: 73-76.

11) Soderholm SC. Proposed international conventions for particle size-selective sampling. Ann Occup Hyg 1989; 33: 301-320.

12) Kenny LC. Developments in workplace aerosol sampling, A review. Analyst 1996; 121: 1233-1239.

13) Harper M. Measurement and monitoring of airborne particles - Techniques and regulations. In: Battle TP, Henein H, eds. Processing and handling of powders and dusts. USA: The Minerals, Metals and Materials Society, 1997: 79-91.

14) Gautam M, Sreenath A. Performance of a respirable multi-inlet cyclone sampler. J Aerosol Sci 1997; 28: 1265-1281.

15) Baron PA. Personal aerosol sampler design: A review. Appl Occup Environ Hyg 1998; 13: 313-320.

16) Koch W, Dunkhorst W, Lodding H. Design and performance of a new personal aerosol monitor. Aerosol Sci Technol 1999; 31: 231-246.

17) Gorner P, Wrobel R, Micka V, Skoda V, Denis J, Fabries JF. Study of fifteen respirable aerosol samplers used in occupational hygiene. Ann Occup Hyg 2001; 45: 43-54.

18）鈴木治彦, 小西叔人, 長原瑞江, ほか. 各種分粒装置の比 較試験結果．第 43 回日本労働衛生工学会抄録集，2003; $22-23$.

19）入江寛文，名古屋俊士，小山博巳，ほか. $4 \mathrm{~mm} 50 \%$ カッ 卜分粒装置付ハイボリウムエアサンプラの質量濃度等価試 験に関する研究. 第 44 回日本労働衛生工学会抄録集, 2004; 36-37.

20）作業環境測定ガイドブック 1. 鉱物性粉じん関係．労働省 安全衛生部環境改善室編, 第 4 版 1998.

21）日本工業規格 JIS Z8814 ロウボリウムエアサンプラ 1994.
22) Berglund RN, Liu BYH. Generation of monodisperse aerosol standards. Environ Sci Technol 1973; 7: 147-153.

23) Carsey TP. LISA: A new aerosol generation system for sampler evaluation. Am Ind Hyg Assoc J 1987; 48: 710-717.

24) Kenny LC, Liden G. A technique for assessing size-selective dust samplers using the APS and polydisperse test aerosols. J Aerosol Sci 1991; 22: 91-101.

25) Chen CC, Lai CY, Shih TS, Hwang JS. Laboratory performance comparison of respirable samplers. Am Ind Hyg Assoc J 1999; 60: 601-611.

26）日本工業規格 JIS Z8901 試験用粉体及び試験用粒子， 1995.

27）日本工業規格 JIS B9921 光散乱式自動粒子計数器, 1997.

28) Baron PA. Calibration and use of the Aerodynamic Paricle Sizer (APS3300), Aerosol Sci Technol 1986; 5: 55-69.

29) Liden G, Kenny LC. Comparison of measured respirable dust sampler penetration curves with sampling conventions. Ann Occup Hyg 1991; 35: 485-504.

30) Myojo T. A simple method to determine the length distribution of fibrous aerosols. Aerosol Sci Technol 1999; 30: $30-39$.

31) Liden G, Kenny LC. The performance of respirable dust samplers: Sampler bias, precision and inaccuracy. Ann Occup Hyg 1992; 36: 1-22.

32) Soderholm SC. Correction. Ann Occup Hyg 1991; 35: 357-358.

33) Heyder J, Gebhart J, Rudolph G, Schiller CF, Stahlhofen W. Deposition of particles in the human respiratory tract in the size range $0.005-15 \mu \mathrm{m}$. J Aerosol Sci 1986; 17: 811-825.

34) Hewett P. Limitations in the use of particle size-selective sampling criteria in occupation epidemiology. Appl Occup Environ Hyg 1991; 6: 290-300.

\section{Assessment of Measured Respirable Dust Sampler Penetration and the Sampling Convention for Work Environment Measurement}

\section{Toshihiko MYOJO}

Department of Work Environment Evaluation, National Institute of Industrial Health, Nagao 6-21-1, Tama, Kawasaki 214-8585, Japan

\begin{abstract}
The relationship between dust size and penetration for a static horizontal elutriator (Sibata C-30) was measured in calm air. The elutriator as a low-volume air sampler is widely used as a dust size classifier in work environment measurements. The actual penetrations were compared with the theoretical models of the sampler and with sampling convention for respirable dust in work environment measurement. The sampling convention was recently introduced into the Japanese standard for work
\end{abstract}

environment measurement and is based on the ISO 7708 respirable dust convention. The bias of sampled masses from the respirable dust was calculated for two flow rates of the sampler, i.e., $50 \%$ cut sizes of $4 \mu \mathrm{m}$ and $5 \mu \mathrm{m}$, from measured penetration curves. The bias of the sampler was overestimated in the $5 \mu \mathrm{m}, 50 \%$ cut condition and underestimated in the $4 \mu \mathrm{m}, 50 \%$ cut condition for most workplace sampling situations.

(San Ei Shi 2005; 47: 239-245) 